\title{
In Conversation with David Clark: Part I
}

Brian Barraciough interviewed Dr David Clark on 1 July 1985 at his home in Cambridge.

BB Morris Carstairs says in the foreword to your book Social Therapy in Psychiatry ${ }^{1}$ that you astonished your contemporaries by becoming at 33 , Medical Superintendent at Fulbourn from senior registrar at the Maudsley Hospital. Why did you do that?

DC There were two professional reasons-I wanted to improve the conditions of long-stay patients in the back wards of the mental hospitals, and I was fascinated by the social approaches being developed in British psychiatry then. I thought this was a chance to try them out. I knew there were the resources, in the staff of the mental hospitals, if they were given a chance to deploy them. Of course, the prospect of consultant pay to a senior registrar with a growing family was attractive.

BB Did you learn that at the Maudsley Hospital?

DC Most of it came before I got into psychiatry, in the Army, and from D. K. Henderson in Edinburgh.

BB How did you come to learn it from the Army?

DC It goes back to my school days. I was at school during the thirties, and in Germany in 1935-36 and I was very frightened by Nazism. I came back from Germany saying there would be a war; the Germans were out to conquer the world and we would have to fight them. In 1939 the war came and I expected to become an Artillery Officer, but as I was a medical student, I was ordered to remain and complete my studies.

BB How old were you in ' 39 ?

DC Nineteen. By 1941 both of my best friends from school had been killed in the War, one in the Mediterranean and one in the Far East. I qualified in 43, and volunteered for the Parachutists. I got involved in the sharp end because I wanted to do something effective quickly. They said at Crookham they wanted medical men in the Parachutists, so I went in.

BB As a doctor?

DC Yes. I saw action in Northern Europe and in the Far East. Two things were particularly important in my service. One was the experience of the conquest of Germany. I was with the 6th Airborne Division that freed Belsen and other concentration camps. The other was in the Far East. I was parachuted into Sumatra to a Japanese internment camp and was given instructions to take over and wait for the British Army to arrive. Three months later there was no sign of the British Army so I had to arrange the transport of five thousand people over the mountains to the British Army enclave on the coast.
BB You had a command?

DC I was sent in as a doctor, but I was the only British officer. I had to become commandant of the camp and chief liaison officer with the Japanese. It was a dangerous time. The camp was burnt to the ground two days after we left and my colleague in the next valley was speared to death. But I got all my people out. It was these experiences that taught me of the extraordinary things that men did to one another and of the immense effect that the environment had on people. I developed a clear view of the power of social factors to help people to change, and this is what my professional life has been about.

BB And Sir David Henderson's influence; he is not thought of as having been interested in social factors?

DC His influence on me began when I was a medical student at Edinburgh. DK was the Professor of Psychiatry and one of the most impressive of the people that lectured to us. I found psychiatry, as he propounded it, deeply interesting because of his interest in people. He used to run an out-patient clinic in front of 150 students. Patients he had never seen before would be brought in and he would take a case history from them, with the audience listening. You could say in a sense that it was a theatre, but it was more than that because he and the patient became absorbed in the story that unfolded. I found this fascinating and thought that psychiatry was one of the subjects I might do. When I came back I asked DK for a job, and did my first three years with him. The people with me were Ivor Batchelor, Kenneth McCrae and Harry Stalker.

BB So you did three years of postgraduate training in psychiatry with Henderson in Edinburgh and acquired the MRCP.

DC Yes. I got the Edinburgh Membership.

BB Was there an Edinburgh Membership in Psychiatry?

DC Yes, but I took it in neurology. And then I took the University of London DPM.

BB And then after Edinburgh?

DC I went to the Maudsley for three years as Registrar and Senior Registrar. I worked on the Professorial Unit under Aubrey Lewis and then in the OutPatient Department with S. H. Foulkes. I had a personal analysis and learned a lot about psychotherapy and group psychotherapy. The Maudsley in the early 1950s was full of the brightest and most ambitious young psychiatrists in Britain. They made an intensely competitive but very stimulating environment. For a time I even thought that I might stay there and began to do some research and 
to write papers. Then I was approached about the superintendent's job at the mental hospital at Cambridge. The job had been advertised and no appointment made. I didn't think it was a good job but I wanted to get practice in facing appointment committees, so I thought, 'A trip to Cambridge, why not?' And so one March day I came to see Fulbourn Hospital. It was an appalling asylumlocked (as they all were then) and grossly overcrowded, worse than most. I thought, 'I can't possibly go there'; but then thought 'they won't give me the job anyway, so why not try the interview just for the practice.' Half way through the afternoon I realised there was a serious chance that I might be offered the job! I nearly bolted back to London, but then I thought, 'I'll give it a try and see.'

BB So at 32, you were the youngest superintendent in the country. What did you find when you got to Fulbourn?

DC A friend said he felt going out to Fulbourn was like cycling back into the nineteenth century. The same three medical gentlemen had run Fulbourn Hospital from 1925 to 1945 and one of them had remained on as superintendent until 1953. The NHS and the twentieth century made hardly an impression on the place.

BB Whom did you succeed?

DC Treharne Thomas. He'd been a notable rugby player and won a Military Cross in World War One. He was a nice man, a kind man, but unhappy with responsibility. He got the superintendency towards the end of his time and didn't enjoy it. The hospital was suffering from indecision at the top and poor management. It was overcrowded and demoralised. There were a few student nurses and no women students at all. Of the five medical staff, three were under notice when I arrived.

BB When was Fulbourn founded?

DC It was opened in October 1858 as the Cambridgeshire and Isle of Ely Pauper Lunatic Asylum. It was run by the County of Cambridgeshire, the Isle of Ely and the Borough of Cambridge. Several active and lively men-Derek Russell Davis, Edward Beresford Davies-were working at Addenbrooke's and also at Fulbourn. There was a lot going on in the admission wards, but the back wards had not been touched since 1939. The staff just kept things going, moderately clean and moderately humane. I applied myself to giving the nursing staff a chance to do for the patients the things they'd always wanted to do. There were quite a lot of male nurses that knew about active therapy and wanted to get the patients working, get the hospital cleaned up and opened up. They wanted to try opening the doors and seeing if it would work. What they needed was somebody who had the courage to stand by them when things went wrong, as of course, they inevitably did. I had the most exciting and rewarding time of my life over the next nine years. In five years, we turned Fulbourn from a closed hospital to a completely open door hospital. We got workshops going, we got halfway houses going, we had Open Days, we brought the public in, we took patients out. We changed the place completely.

BB How many mental hospitals in England had been reformed by 1953 ?

DC Dingleton and Mapperley were open door hospitals by 1953 and two or three others were a good way towards it. We joined them and moved briskly forward with them.

BB Where did these reforming ideas come from?

DC Various sources. It has always been known that you could open doors. Saxty-Goode did it at Littlemore in the 1930s, and it had been done in Scotland in the 1870s. The value of work for patients was known to Conolly and Pinel, and Hermann Simon had shown it again in Germany in the twenties. Much of what we did was a return to the principles of sound asylum management, known for a century. The principles had been lost in the development of so called 'scientific psychiatry' and in the overcrowding of the asylums during the latter part of the nineteenth and early twentieth centuries. Another source of ideas was the people who came back from the war determined to make things better. McDonald Bell at Dingleton for instance could not stand the squalid brutality of the old asylum. He said, 'Either I unlock the doors or I leave psychiatry'.

Then there were the sociologists-Goffman, Belknap, Dunham-who demonstrated the effects of prolonged incarceration on people, and suggested that a lot of what we called chronic schizophrenia might be due to twenty years in the environment of the back wards.

It was also partly the spirit of the times, of the Welfare State. We wanted to dismantle authoritarian, prewar society and reform all institutionsschools, mental hospitals, hospitals, jails, and make them more humane.

BB Do you understand what went wrong with the asylums? They started with good intentions.

DC Yes, they did. Fulbourn was much better in 1865 than in 1910. The history of Fulbourn on which I am currently working shows that clearly. The same happened in Germany, America and France.

One element, undoubtedly, was increasing size. The asylums were made larger and larger. More and more patients were put in but less and less money spent, so the asylums became impoverished both in material standards and quality of life. Society's attitude towards unfortunates also changed. In the second half of the nineteenth century, with the 
influence of Social Darwinism, there was less concern for the unfortunate and a feeling that the mad ought to be locked up. The 1890 Act is very different from the 1845 Act: the 1845 Act is about running good hospitals and the $1890 \mathrm{Act}$ is about locking people up. I believe doctors changed too. In the first half of the nineteenth century, a lot of gentlemen with medical degrees, such as Conolly, Kirkbride, Bucknill, and Hack Tuke, wanted to improve society and were proud to work in the new asylums. Then medicine became organised. Advances in knowledge came from strict attention to pathology and bacteriology. The doctors in the asylums, instead of going out and playing cricket with patients, sliced up the brains of deceased patients in the hope of finding the cause of schizophrenia.

BB How did you come to be good at running things? Do you think it's inherited?

DC No, I think I learnt a lot of it in the Army. How many 26-year-olds have the chance to manage a camp containing 5,000 people and then to take them out to safety?

BB Was that your first experience of a large administrative task?

DC Yes.

BB Well then, the Army couldn't have taught you how to do it.

DC Well no, I had small administrative tasks in the Army. The first was to take a heterogeneous group of reluctant men and turn them into a field ambulance section, to run a dressing station. Half of them were conscientious objectors and the other half were reluctant conscripts into the RAMC who found themselves together in this unit. It was my job to help them to see that our survival depended on our working together.

BB I still don't find that a satisfactory explanation of how you came to enjoy and be confident at administering things. Perhaps you have always been well organised, and enjoyed making things work.

DC Yes, there may be something in my personality. I enjoy helping a group of people to find out what they want to do and then helping them to get it done.

BB What about your family background?

DC My father was a medical scientist, a pharmacologist, author of Clark's Applied Pharmacology. ${ }^{2} \mathrm{He}$ came of a Quaker family. My mother had been a teacher. We were brought up in a Quakerly way with an emphasis on taking responsibility, thinking ahead, being orderly and planned and effective, so that certainly came from there.

BB Did you go to a Quaker school?

DC No, I went to George Watson's Edinburgh. When it became clear that I was interested in biology and fairly good at exams, my father determined that I should follow him. He got me into Watson's which had good science teaching and arranged for me to go to Cambridge, to his old college, King's, so that I should get a medical degree. The war intervened and I had to go back to Edinburgh to do my clinical training until I qualified in 1943. And that was when things began to change for me. I realised that I was not going to make a medical scientist like my father.

BB What did your father think of your choice of career?

DC He died in 1941 before I had made my choice. He was only interested in pure scientific research. Whether I would have retained his respect as a psychiatrist I don't know.

BB What about others of your family?

DC One sister, a doctor; one brother in the family firm; the other sister married a school teacher.

BB Well, let us return to Fulbourn. You went there in 1953; had you worked in a mental hospital before?

DC I had worked at Craig House for three years. I knew all about 'bins', which was why I felt the Maudsley so unreal.

BB What about the Social Psychiatry Research Unit? DC It had barely started in those days: it was much later that John Wing did such a magnificent job for those of us who are concerned about people in the back wards. But that wasn't the Maudsley in the early ' 50 s.

BB Can you describe what a back ward was like at Fulbourn in 1953?

DC You were taken in by somebody who had a key who unlocked the door and locked it behind you. The crashing of the keys in the locks was an essential part of asylum life then just as it is today in jails. You'd be shown into a big bare room, overcrowded with people, with scrubbed floors, bare wooden tables, benches screwed to the floor, people milling around in shapeless clothing. There was a smell in the air of urine, paraldehyde, floor polish, boiled cabbage and carbolic soap-the asylum smell. Some wards were full of tousled, apathetic people just sitting. You'd see twenty people sitting in a row. Later you learned that one of the reasons they were sitting in a row was that for twenty years the nurses had been saying, 'Sit down, shut up'. Others were noisy. The disturbed women's ward at Fulbourn was a phantasmagoric place. The women were in 'strong clothes', shapeless garments made of reinforced cotton that couldn't be torn. Many of them were in 'locked boots' which couldn't be taken off and thrown. There was nothing moveable. There were no knives. Spoons were taken in and counted after every meal. The women all had their hair chopped off short giving them identical wiry grey mops. As soon as you came in they'd rush up and crowd round you. Hands would go into your pockets grabbing at you, pulling at you, clamouring 
for release, for food, for anything, until they were pushed back by the sturdy nurses, who shouted at them to sit down and shut up. At the back of the ward were the padded cells, in which would be one or two naked women smeared with facces, shouting obscenities at anybody who came near.

If a ward was well under control you didn't see many fights. The fights occurred after the medical staff had left. But if they were not managing very well, you'd see fights, hair pulling, screaming, with the nurses piling in on top and pulling them apart. On some wards, there was an air of tremendous tension. You felt frightened the whole time, and watched your back. You knew there was a very real chance that somebody would try to hit you with something.

Then there were the airing courts. Grey, big courts, paved with tarmac, surrounded by a wall twelve feet high and a hundred men milling around. A few of them walking, some running, others standing on one leg, posturing, with the urine running out of their trouser leg, some sitting in a corner masturbating. A couple of bored young male nurses standing on 'point duty', looking at them, ready to hit anybody who got out of line, but otherwise not doing anything. A scene of human degradation.

BB And what drugs were available?

DC Paraldehyde. Barbiturates were used, but you had to be careful because people died if you gave them too much. In an emergency a compound injection of hyoscine and morphine was given to sedate. If it was believed a patient had been creating trouble deliberately, an intramuscular injection of paraldehyde combined sedation with punishment; very painful and often caused an abscess.

BB And what did people do all day?

DC Quieter patients often had jobs. The hospital was run by unpaid patient labour. They staffed the laundry, many workshops, the farm and garden, the kitchens, and scrubbed the corridors. At Fulbourn there was a squad of women who scrubbed from one end of the hospital to another every week, then they scrubbed back again. Quite a lot of men worked out of the wards. There were prestige jobs on the farm, in the gardens, in the stores, in the engineers' workshops. There were jobs enough so that the quieter, well adjusted, not too impaired patients led quite reasonable institutional lives. You didn't see them much on the wards. The patients on the wards did nothing. The job of the staff was to see they came to no harm, and did no harm to each other.

BB And night-time?

DC That was unspeakable. There were 80 beds to a dormitory.

BB Eighty?

DC Eighty, with a chamber pot under each. The beds were so close together that the men could not get up between their beds, so they climbed over the ends to get out. It wasn't well ventilated, and on a summer's night it stank of urine and of paraldehyde.

BB How were the patients kept clean?

DC Once a week was bathing day. They were all stripped and driven into the big communal bathroom where they were bathed, scrubbed, inspected for scabies and nits and driven out the far end to get fresh clothes.

BB How was time broken up?

DC There was a pattern to the day. The patients were turned out to the airing court, counted out and counted in. Then they were sat at their tables for their meals; spoons and forks handed out and the food put on the table. The charge nurse said grace and they were allowed to eat. Then the spoons and forks were all taken in and washed by the staff and counted. Nobody left the table until all the cutlery was counted. As in the Army everything took a terribly long time because there were too many people using inadequate facilities. People were put into the lavatories in batches and kept there until everyone's bowels had moved.

BB What about the week and the year?

DC There were the traditional festivities. The galas were tremendous occasions, such as the hospital Christmas and the annual fete and sports in the summer. There were weekly film shows at Fulbourn, only of course for the better patients, and there was the Chapel on Sunday. That was the one occasion that they had the chance of seeing the opposite sex. There was the hospital cricket team, composed mainly by staff, but when there were competent patients, they were taken into the team, which played regularly. Parole patients were taken out to watch the cricket. And there were walks around the grounds. Twenty patients, one nurse at the front, one at the back, two at the sides, to make sure that nobody escaped; counted out and counted in of course.

BB And personal property?

DC On the privileged wards patients were allowed a little property, but none on the disturbed or 'wet and dirty' wards. On many wards, the patients' clothes were rolled up at night and taken in and put in a cupboard, and issued again the following morning. No patient was allowed to have money, that was contraband, and they were punished if found with it.

BB And how was the institution run?

DC The job of the nurses was to watch the patients to see that they didn't escape or harm one another. The job of the doctors was to watch the nurses to see they didn't steal the patients' food and didn't abuse the patients. One of your main jobs as a doctor was to examine bruised people, be told about how they acquired the bruises and then to 
decide whether it was so flagrant that you had to hold an enquiry. In one hospital I had a patient who was killed by the nurses; he attacked the nurses, they beat him up and he died of a retroperitoneal haemorrhage. Deliberate violence by the staff to patients varied a great deal, there wasn't very much of it at Fulbourn, but there were always people amongst the staff who thought it was their duty to 'show them who is the boss'. As a doctor, your job was to hold the balance, to see that it didn't get too far out of hand.

BB And the superintendent?

DC To watch the doctors, and also to watch other people and check thefts and abuses. For example, soon after I arrived at Fulbourn the Group Secretary came to me and said, 'Sir, there is a leg of lamb missing from the kitchen. Would you hoid the usual enquiry?' I spent a whole afternoon crossquestioning a set of shifty cooks to find out who had stolen the leg of lamb. I never did find out.

BB What were the powers of the superintendent?

DC Absolute.

BB What do you mean by that?

DC Well, he could fire anybody in the place except for five named officers appointed by the Committee, but those he could suspend. Anybody else, he could fire on the spot if he saw fit. He would have to justify it later, of course. But Fulbourn Hospital had scarcely realised that the world had changed.

BB When did medical superintendents begin?

DC The earliest asylums had various people in charge, but gradually the idea developed that medical gentlemen were the most suitable people to put in charge of asylums. It wasn't until the middle of the nineteenth century that the idea of a Hospital Management Committee appointing a doctor and making him all-powerful became established. In the early days at Fulbourn, after an enquiry, the Committee put the clerk and steward under the order of the superintendent to prevent him stealing the patients' food, as the previous one had.

BB What was the training of a superintendent?

DC Until the National Health Service began in 1948 the superintendent was paid more than the deputy superintendent and much more than the assistant medical officers. A doctor who went to work in the asylum and liked the life, and decided to stay, worked for promotion; in due course he became a deputy. Then if he wanted to live well, he applied for superintendent vacancies. The doctors who became superintendents were mostly men in their mid-fifties with many years of asylum experience behind them. When the NHS came all the senior asylum doctors became consultants and there was no extra money for being a superintendent, so nobody wanted the superintendent's job. That's why younger doctors like myself got the superintendencies in the mid-fifties. Nobody with any sense took the job because you had to carry far more responsibility than any of the other consultants, but received no more than them. The Management Committee, a group of city and council councillors, appointed the superintendents to run the place.

BB Until retirement?

DC Yes. Ten years was the average. The superintendent was answerable to the Committee for everything that happened and also answerable in law. If a certified patient escaped and broke into a house and stole, the only person the aggrieved householder could sue was the medical superintendent. So within the hospital he had absolute power. In the thirties, when jobs were desperately short, the fear of instant dismissal was very real. Fulbourn was full of stories of people whom the superintendent sacked out of hand. For instance, the superintendent saw a nurse hand a key to a patient, and fired him on the spot. So everyone was terrified of the superintendent. There were signalling systems in the hospital, passing the message from ward to ward when the superintendent was coming round, by tapping with a key on the central heating pipes, one tap for the junior doctor, two for the chief male nurse, three for the superintendent. Another method was to have patients watch for the superintendent. In the 'disturbed' ward at Fulbourn there was one patient who sat by the door and whenever I came in he leapt to his feet and shouted 'Doctor' at the top of his voice. At first I thought he was saluting me but then I realised his job was to warn the charge nurse to stop whatever he was doing, and come out in case the superintendent saw.

The place was run like a jail; authority was punitive and fault finding. The hospital was riddled with curious covert devices. Part of the art of being a superintendent was knowing what was going on but not admitting that you knew. I learnt this from the Army. To be an effective commissioned or noncommissioned officer in the Army, you have to know the crooked things that people do and you have to know how to stop them without openly declaring that you know. If you make it clear that you know, you then have to punish.

BB What made you think you could be a successful superintendent?

DC I don't think I faced that question before I took the job. As I told you, I applied for the job lightheartedly, and only discovered the night before that they were taking my application seriously. I wanted to be a consultant and I believed that I could change things in the back wards of a mental hospital.

BB You could see a job.

DC I could see a job, yes. I had worked in hospitals that were in touch with the modern world, but I hadn't realised that Fulbourn hadn't moved out of the 
between wars period. The most powerful person in Cambridgeshire was the Lord Bishop of Ely. The Anglican Church still held vast power.

BB How did that affect you?

DC I remember I was concerned about whether I dare affirm at inquest rather than swear on the Bible. It is a Quaker tradition and I was an agnostic. But I knew that it would cause a lot of offence and head shaking amongst the Committee if they found out that they'd got a person who wasn't a member of the Established Church. It was the world of Trollope, of Barchester Towers.

BB What about the superintendent and the other consultants?

DC The relationship of the medical superintendent with the other consultants bedevilled many hospitals right through the 1950 s and 1960 s, but it was not an important issue at Fulbourn. The consultants working in Cambridge were far better clinicians than I was, so it never occurred to me to interfere with what they were doing. I respected what they were doing with their patients and they came to respect what I was doing with the back wards and we didn't interfere with one another.

BB We have reached a point where we could begin talking about what you felt you had to do when you got to Fulbourn. Did you make a diagnosis as it were, and prescribe treatment?

DC My first job was to get the hospital running effectively. This involved listening to what people had to say. My predecessor used to see everybody separately. I thought this wasn't a very good idea. The doctors were coming to me to complain about the matron, the matron was coming to complain about the doctors; she also complained about the Group Secretary, who came to complain about the chief male nurse, who came to complain about the engineer. I thought, 'This is silly!' So I arranged meetings of the medical and nursing staff, to decide about difficult patients. I started arranging meetings with the hospital officers to decide what jobs should be done next. This seemed to me obvious, but it was a revolution.

BB Was there no regular meeting of the chief nurse, chief administrator and so on?

DC None, before I came. The introduction of democratic concensus methods was a wonderful change for everyone. They knew what was going on and they got on with things. Then we began to consider improvements. I visited progressive hospitals, and came back with ideas. I said, 'Why don't we open some ward doors? We talked about it and then we opened the doors of two or three wards, where all patients had parole. Then over a period of five years we opened other doors and found out what was possible. We did it by consultation and discussion. I had many meetings with the charge nurses-they were a wonderful powerhouse of change.
BB You saw the group of charge nurses as the people who carried the hospital culture?

DC Undoubtedly. This group of middle aged men and women who had worked in the place ten or twenty years, and who had still got vigour and enthusiasm, were the carriers of the old culture, but they were also the creators of the new.

BB Did you send them away to see Dingleton and Graylingwell?

DC Yes, those that wanted to. We promotod people who wanted to change things, rewarded people who changed things, and scoffed at those who didn't.

BB How did you decide what to do?

DC It was not a question of me deciding, but the nurses and myself deciding together. Many had worked in hospitals where there was activity.

BB You have described how back ward patients did nothing.

DC There were hospitals in Britain where the patients were active, but the easier thing for the doctor in charge is to say, 'Don't let that patient out.' It's more difficult to say, 'Let him out rather more often.' When they say, 'What'll happen if he hits someone?', you have to say, 'I'll answer for that!' I came to see in later years that my job had been to give people a feeling of security, of being backed, of being trusted, a belief that if they took risks, they wouldn't be abandoned to a Committee of Enquiry. The therapeutic potential was there in those staff, but the tradition of medical management that had grown up in the twenties and thirties was an anxious checking of developments. People like Duncan McMillan at Mapperley, T. P. Rees at Warlingham and Joshua Carse at Graylingwell were doing all sorts of things, but many hospitals had old men in charge, who always said, 'No, no, don't do that, something dreadful might happen.'

That was the first phase, opening the doors. The next aim was to improve the life of the patients on the back wards. So I started picking up ideas, work for in-patients, get the place cleaned up, accommodation improved.

BB What does work mean in that setting?

DC We put out gangs of men with hoes and dug up all the weeds. The hospital grounds were full of weeds, and there was a great tangled overgrown shrubbery that had got out of hand during the war. We took the men out and they dug it all out. One of our big projects was a new sports field. We built a complete sports field in the front of the hospital. I can remember times when we had fifty or sixty wheelbarrows going, with patients shovelling soil into wheelbarrows, wheeling it, dumping it.

BB For pay?

DC For reward, not pay. It was some years before we could give them money.

BB What were the rewards?

DC Tobacco, sweets, privileges. Later I managed to get 
permission to pay. It wasn't very much money, but something they could spend as they wished.

BB That was to give purpose to the waking day?

DC Yes. Then we began to look at improving the quality of life. For instance, letting people have private property. We had to persuade the Management Committee to buy lockers for the patients, a new idea. Then we began to review the penal restrictions. In 1953 out of 950 patients there were fifteen who had town parole. Each of the fifteen had a 'parole card' which had to be personally signed by the superintendent on Friday. I said, 'This is absurd. Let's scrap the whole system.' We extended the number of people allowed to go into town and the number of people allowed to go out of the ward into the grounds.

BB That's devolving responsibility downwards.

DC Yes, and dismantling the absurd and meaningless rules of the custodial structure.

BB For example?

DC Somewhere rules had originally been quite sensible, but had been subsequently misapplied destructively. I discovered for instance, that any patient who had ever had a fit, had to stay permanently on the 'disturbed' ward, and sleep in an observation dormitory with a hard pillow, because once, in the distant past, an epileptic had a fit in a non-observed place, and smothered in his pillow, and the coroner criticised the hospital. The result was that a number of well behaved, competent asylum patients, who had once had a fit, sometimes years before, were forced to live in a violent degrading place, and sleep in discomfort, in a grossly overcrowded dormitory. I said, 'Let us review all these people; if there is somebody who has a fit every night, of course be must be under observation, but if somebody hasn't had one for over a year, let him take his chance.' I explained that we would point out to the coroner that all epileptics in general society accepted the risk of smothering but that they did not let it cripple their lives. So this small group of elite workers were pathetically grateful for having been allowed out of the 'disturbed' ward.

Suicide caution cards were another. If a doctor considered someone suicidal, he made out a red card, with the name of the patient at the top. Every member of staff who came on the ward had to sign the card and a declaration that he knew the patient was a suicidal risk and must be kept under observation at all times. This procedure for setting up suicide caution cards was well established, but the procedure for cancelling them was not. So they were seldom cancelled. On the 'disturbed' ward there were fifteen people on SCCs. Everybody solemnly signed the cards. I said, 'Let's look at these people.' One had made a suicidal attempt three years before; it was completely irrelevant, yet he was still being watched, policed, harassed and degraded. So we scrapped the system. We did give a lot of time and thought to people we thought were suicidal and arranged for them to be with someone, but we didn't routinise it. In any organisation you have to revise the rules constantly to make sure that they remain sensible.

We had a slogan, 'Activity, Freodom, Responsibility', the three things we wanted to re-introduce into the lives of patients. Activity, we have talked about, freedom we've talked about. We wanted to give them more responsibility for their own lives. A simple device was self-governing arrangements on the ward, letting patients docide when they could have their meals, for example, which was first seen as revolutionary. In the old asylum anybody who was a patient was, by definition, irresponsible and unable to do anything. In fact many patients were responsible and capable of dressing themselves, managing their money and living their lives, looking after themselves, and choosing when to have their meals. But because of the blanket rules, everybody had been treated the same way. Beginning to challenge that and beginning to develop autonomy both for individuals and for groups within the hospital was the next thing we worked on in the sixties.

BB Were the patients compulsorily detained?

DC In the middle fifties, 90 per cent of patients were certified. There were a few voluntary patients who were on the admission wards, but on the back wards everyone was certified.

BB So that gave legal backing for total control.

DC In the decade before the 1959 Act there was a ferment of discussion throughout British psychiatry. There were experiments with relaxing legal restrictions. I started discharging people from their certificates. And when the appointed day came in 1959, we discharged the lot! After a period of adjustment we settled down to about 12 per cent of our admissions and 8 per cent of the resident hospital population as detained patients.

BB You were talking about responsibility.

DC We tried to develop self-government. One of the first therapeutic communities at Fulbourn was run by Eddy Oram on Adrian Ward in 1958-1960, a women's convalescent ward, and was published in Human Relations. ${ }^{3}$ In the early sixties, we began changing the disturbed wards, I ran a therapeutic community on the women's 'disturbed' wards. Then we put the men's 'disturbed' wards and the women's 'disturbed' wards side by side and ran them both as therapeutic communities. Then we combined them, as 'Hereward House'.6.7 That was the most exciting, the most interesting period of my work, and where I personally learnt a great deal. The patients and nurses challenged me about authority ploys that I'd taken for granted. Though I had been involved in bringing in humane and 
liberal reforms, I had maintained a considerable control over many areas. They forced me to see that some of these controls were no longer helpful. We looked at them, and challenged them and worked out our own rules, the patients and the staff together, within the therapeutic community.

BB You came in a benign tyrant.

DC Yes.

BB With the aim of introducing reform and giving people more responsibility over what they did, but you retained ultimate control.

DC That's true of the first ten years.

BB How far did you go in relinquishing control and how did you finally give it up completely, as I imagine you did?

DC I came in ' 53 and found I'd got the paraphernalia of power of the superintendent of the previous generation. Not only that but all kinds of bizarre tasks. I was told it was my duty to read the lesson in the Chapel at least once a month, and to examine the pigs at least once a week, and to do a postmortem on every patient who died, so as to check whether the doctor had treated them adequately.

BB You gave up the pigs?

DC No, I continued looking at the pigs, because I enjoyed looking at pigs. But I made it clear that I could accept no responsibility for their welfare.

BB And the lesson in the Chapel?

DC Because I was an agnostic, that bothered me. First of all I said I would only read the lesson at the great festivals, and then after a year, I refused to do even those. The post-mortems I did for about three or four months, and then said that I thought it was really absurd, and that if we had wanted to know what people died from it, we'd better get a pathologist to do it. I started off by giving up a whole lot of the rather pointless aspects of the superintendency, but I was still responsible to the Management Committee for the way that the hospital ran. During the sixties, with ferment generally, a number of these things were challenged, and quite rightly; for instance, the old secretary retired and we'd got some modern administrators. They made it clear they were not going to be responsible to the superintendent. I thought they were entirely right. But I still retained a residual responsibility for the way the place ran. Then, in 1971, preparing for the cogwheel reorganisation, we officially abandoned the title of medical superintendent. But really, for about five years before that it had been a title, and I hadn't used the authority inherent in it. The super- intendency vanished in 1971, and I became the first Chairman of the Division of Psychiatry.

BB Did you have your own HMC?

DC Very good. I was fortunate there. My first chairman was Lady Adrian; the next chairman was Alderman Mallett, an ex-mayor of Cambridge, then Sir Henry Willink, an ex-Minister of Health and Master of Magdalen College, and the last, Mrs Pauline Burnet. All of them outstanding, able, charming people and all deeply committed to the welfare of the hospital.

In retrospect it it clear that Fulbourn Hospital was fortunate. It had its own good Hospital Management Committee from 1951-1974. The members were interested in running the hospital for the benefit of the patients and saw to it that the patients' needs were predominant. They had their own budget, it was small but they managed it well. There was a great deal of building at Fulbourn during those twenty-three years, and the physical conditions were vastly improved.

The early seventies were unfortunate for Fulbourn Hospital because of the lack of money. But we were particularly affected because we were thrown in with Addenbrooke's at a time when Addenbrooke's was just moving into a new building inadequately funded. Any spare money in Cambridge was sucked into their vortex. The problem of getting a great big new DGH going absorbed everybody's energies. There was a neglect of the needs of the mental hospital up the road. So there was a relative neglect of the long-term patients within Fulbourn. Because Fulbourn had a high morale, it has kept going far better than many of the hospitals that I know, and it still is doing a good job. But compared with the '50s and ' 60 s when the hospital was getting public support and acclaim and really moving forward, they've had to battle on looking after the long-term people without much help from either the financial side, the administrative side or the newly appointed academics.

BB So Fulbourn lost, you think, on balance?

DC Yes, compared with the way things were ten or fifteen years ago. It's all rather sad; but compared with the state that many mental hospitals are in, it's still good. I've been to places I knew as good hospitals ten years ago, which have slid way downhill.

(The references will appear with Part II of this interview which will be published next month.)

\section{Search for Twins with Post-Partum Psychosis}

I should be very grateful if anyone who knows of twins, at least one of whom has suffered a post-partum psychosis, would kindly contact me: Professor I. F. Brockington,
Department of Psychiatry, University of Birmingham, Edgbaston, Birmingham B15 2TH. 